\title{
Table of Contents Volume 10, 2005
}

\section{Original Articles and Reviews}

1 Psychobiological Theories of Smoking and Smoking Motivation

Claudia Lujic, Martin Reuter, and Petra Netter

25 Risk Attitudes and Behavior Among Norwegian Adolescents: The Effects of a Behavior Modification Program and a Traffic Safety Campaign Hilde Iversen, Torbjørn Rundmo, and Hroar Klempe

39 Polish Psychology in the Period of Political Transformation (1989-2003)

Jerzy Brzeziński and Jan Strelau

51 Estimates of Multiple Intelligences: A Study in Poland

Adrian Furnham, Agata Wytykowska, and K.V. Petrides

60 Affective Concomitants of Information on Morality and Competence

Bogdan Wojciszke

83 Editorial

Rainer K. Silbereisen

86 The Implications of the "Bologna Process" for the Development of a European Qualification in Psychology Ingrid Lunt

93 Definition and Assessment of Competences in the Context of the European Diploma in Psychology Dave Bartram and Robert A. Roe

103 Balancing Individual Interests and Quality of the Profession in the Formulation of Professional Standards Ype H. Poortinga

110 Commentaries on the Articles by Lunt, Bartram and Roe, and Poortinga Rudolf Fisch; Norah Frederickson

113 Reply to the Commentaries on the Articles by Lunt, Bartram and Roe, and Poortinga Ingrid Lunt

116 Women's Psychological Distress in Midadulthood: The Role of Childhood Parenting Experiences

Eirini Flouri
124 Trauma and Temperament as Predictors of Intensity of Posttraumatic Stress Disorder Symptoms After Disaster Jan Strelau and Bogdan Zawadzki

136 Can Aggression Provide Pleasure? J. Martin Ramírez, Marie-Claude BonniotCabanac, and Michel Cabanac

229 Psychology and Design Processes Bernhard Wilpert

237 Commentaries on "Psychology and Design Processes" by Bernhard Wilpert

Christian Dormann and Norbert K. Semmer

224 The Relationship Between Generalized Resistance Resources, Sense of Coherence, and Health Among Finnish People Aged 65-69 Sanna Read, Kaisa Aunola, Taru Feldt, Raija Leinonen, and Isto Ruoppila

\section{Special Section: Motivation and Affect in the Self-Regulation of Behavior}

173 Introduction Anastasia Efklides

175 Interest as the Missing Motivator in Self-Regulation

Carol Sansone and Dustin B. Thoman

187 The Role of Mood States in Self-Regulation: Effects on Action Preferences and Resource Mobilization

Guido H.E. Gendolla and Kerstin Brinkmann

199 Social Interaction - What Can It Tell Us about Metacognition and Coregulation in Learning? Pekka Salonen, Marja Vauras, and Anastasia Efklides

209 Subliminal Affect Regulation: The Moderating Role of Action vs. State Orientation Nils B. Jostmann, Sander L. Koole, Nickie Y. van der Wulp, and Daniel A. Fockenberg 
218 Self-Regulation After Mortality Salience: National Pride Feelings of Action-Oriented German Participants

Miguel Kazén, Nicola Baumann, and Julius Kuhl

\section{Special Section: Human Development and Well-Being}

259 Introduction

Katariina Salmela-Aro and Ingrid Schoon

264 The Investigation of Optimal Experience and Apathy: Developmental and Psychosocial Implications

Antonella Delle Fave and Fausto Massimini

275 Affective and Social Self- Regulatory Efficacy

Beliefs as Determinants of Positive Thinking and Happiness

Gian Vittorio Caprara and Patrizia Steca

287 Childhood Roots of Women's Subjective Well-

Being: The Role of Optimism

Daiva Daukantaite and Lars R. Bergman

298 The Role of Family Background, School Success, and Career Orientation in the Development of Sense of Coherence Taru Feldt, Katja Kokko, Ulla Kinnunen, and Lea Pulkkinen

309 Combining Work and Family Life: Life Satisfaction Among Married and Divorced Men and Women in Estonia, Finland, and the UK Ingrid Schoon, Leeni Hansson, and Katariina Salmela-Aro
320 Positive Adult Personality Development: Adjustment and/or Growth?

Ursula M. Staudinger and Ute Kunzmann

330 Is Life Getting Better? How Long and Happily

Do People Live in Modern Society?

Ruut Veenhoven

\section{Reports}

71 Does Psychology of Religion Exist?

Kenneth Brown

146 Evaluation of "Vital Aging-M": A Psychosocial Program for Promoting Optimal Aging Rocío Fernández-Ballesteros

157 Commentaries on "Evaluation of "Vital AgingM"' by Rocío Fernández-Ballesteros David M. Almeida; Andreas Kruse

160 The Adaptation of Three Subjects from the First Year of Psychology Studies of the University of Salamanca (Spain) for Teaching Within the Framework of the European Credit Transfer System (ECTS)

José M. Arana, M. Ángeles Mayor, Begoña Zubiauz, and David L. Palenzuela

\section{News, Reviews, and Announcements}

74, 76, 78, $165 \quad$ News

81, 170, 256, 347 Calendar

79, 254, 344, 345 Book Review

349 Reviewers 2005

350 Table of Contents / Keyword Index / Author Index, Volume 10, 2005 